\title{
AKTIVITAS ANTIHIPERTRIGLISERIDA DAN ANTIHIPERGLIKEMIK EKSTRAK DAUN \\ KELOR (Moringa oleifera Lam.) PADA TIKUS HIPERTRIGLISERIDA DIABETES
}

\author{
THE ANTIHYPERTRIGLYCERIDE ACTIVITY AND \\ ANTIHYPERGLYCEMIC OF ETHANOL EXTRACT \\ OF MORINGA LEAVES (Moringa oleifera Lam.) \\ ON HYPERTRIGLYCERIDE \\ DIABETES RATS
}

\begin{abstract}
Elly Wardani, Hadi Sunaryo, Muhammad Zaki Sopiani, Mulki Fatahillah
Fakultas Farmasi dan Sains Universitas Muhammadiyah Prof. Dr. Hamka Email : ly.wardanie@yahoo.co.id; hadi_itb@yahoo.com
\end{abstract}

\begin{abstract}
ABSTRAK
Gaya hidup yang tidak sehat (obesitas) menjadi pemicu utama meningkatnya prevalensi diabetes mellitus dan aterosklerosis atau bahkan komplikasi keduanya. Tujuan penelitian ini untuk mengetahui bagaimana pengaruh pemberian ekstrak etanol $70 \%$ daun kelor (Moringa oleifera Lam.) terhadap penurunan kadar trigliserida dan glukosa darah pada tikus putih hipertrigliseridemia dan diabetes. Penelitian ini menggunakan 30 ekor tikus yang dibagi menjadi 6 kelompok. Sebagai bahan pembanding digunakan Fenofibrat dengan dosis $9 \mathrm{mg} / \mathrm{KgBB}$ dan Glibenklamid dosis 0,9 mg/KgBB. Bahan uji diberikan selama 21 hari menggunakan 3 variasi dosis, yaitu $150 \mathrm{mg}$, $300 \mathrm{mg}$ dan $600 \mathrm{mg} / \mathrm{KgBB}$. Berdasarkan hasil uji analisa statistik ANOVA satu arah disimpulkan bahwa dosis $300 \mathrm{mg} / \mathrm{KgBB}$ dan dosis $600 \mathrm{mg} / \mathrm{KgBB}$ mempunyai aktivitas yang sama dalam menurunkan kadar trigliserida darah dibandingkan dengan kontrol positif Fenofibrat dosis $9 \mathrm{mg} / \mathrm{KgBB}$. Sedangkan ekstrak etanol $70 \%$ daun kelor dosis 150 $\mathrm{mg} / \mathrm{KgBB}, \quad 300 \mathrm{mg} / \mathrm{KgBB}$ dan $600 \mathrm{mg} / \mathrm{KgBB}$ mempunyai kemampuan menurunkan kadar glukosa darah tikus yang diinduksi aloksan dan pakan tinggi trigliserida sebanding dengan Glibenklamid dosis $0,9 \mathrm{mg} / \mathrm{Kgbb}$.
\end{abstract}

Kata Kunci : Daun kelor, diabetes mellitus, trigliserida, glukosa darah 


\begin{abstract}
Unhealthy lifestyle increas the prevalences of diabetes mellitus and atherosclerosis or both complications. The study purpose is to find out how the moringa leaves ethanol extract may act as anti-hypertriglyceridemia in hypertriglyceridemia and diabetes rats. The study used 30 rats were divided into 6 groups. As anti-hypertriglyceridemia drug used fenofibrate $9 \mathrm{mg} / \mathrm{KgBW}$. The moringa leaves extract are given for 21 days using 3 dose variations, are $150 \mathrm{mg}$, $300 \mathrm{mg}$ and $600 \mathrm{mg} / \mathrm{KgBW}$. The results concluded that dose $300 \mathrm{mg} / \mathrm{KgBW}$ and dose $600 \mathrm{mg} / \mathrm{KgBBW}$ have the same activity as anti-hypertriglyceridemia with positive control Fenofibrate $9 \mathrm{mg} / \mathrm{KgBW}$. All doses of ethanolic extract of moringa leaves can decrease blood glucose levels on hypertriglyceridemia rats induced with alloxan and comparable with that of Glibenclamide $0.9 \mathrm{mg} / \mathrm{KgBW}$.
\end{abstract}

Keywords : Moringa leaf, diabetes mellitus, triglyceride, blood glucose

\section{PENDAHULUAN}

Diabetes mellitus

(DM)

didefinisikan sebagai suatu penyakit atau gangguan metabolisme kronis dengan multi etiologi yang ditandai dengan tingginya kadar gula darah disertai dengan gangguan metabolisme karbohidrat, lipid dan protein sebagai akibat insufisiensi fungsi insulin (Depkes RI, 2005). Insulin adalah hormon anabolik (pembentuk) utama tubuh dan memiliki berbagai efek lain selain menstimulasi transport glukosa, insulin juga meningkatkan transport asam amino ke dalam sel dan menstimulasi sintesis protein (Corwin, 2009).
Diabetes Melitus terdiri dari dua tipe yaitu tipe pertama yang disebabkan keturunan dan tipe kedua disebabkan life style atau gaya hidup. Secara umum, hampir $80 \%$ prevalensi diabetes melitus adalah diabetes mellitus tipe 2 . Ini berarti gaya hidup atau life style yang tidak sehat menjadi pemicu utama meningkatnya prevalensi diabetes mellitus. Bila dicermati, penduduk dengan obesitas mempunyai risiko terkena diabetes mellitus lebih besar dari penduduk yang tidak obesitas (Depkes RI, 2012).

Gambaran dislipidemia pada diabetes mellitus tipe 2 yang paling sering ditemukan adalah peningkatan kadar trigliserida dan penurunan 
kadar high density lipoprotein

(HDL). Pada penderita diabetes mellitus terdapat peningkatan asam lemak bebas dalam darah dan kadar asam lemak bebas tersebut sejalan dengan naik turunnya kadar glukosa darah. Peningkatan kadar asam lemak bebas dalam darah dapat mengurangi sensitivitas jaringan terhadap insulin. Hal tersebut menyatakan bahwa terdapat hubungan antara kadar trigliserida dengan diabetes. Manifestasi gangguan metabolisme lemak sedemikian menonjol sehingga diabetes mellitus pernah disebut lebih merupakan penyakit metabolisme lemak dari pada metabolisme karbohidrat (Josten, 2006).

Salah satu tanaman obat yang dapat digunakan sebagai obat antidiabetes adalah daun kelor. Kelor dimanfaatkan biji, daun, hingga kulitnya (Kasolo et al., 2010). Penelitian tentang aktivitas tanaman kelor sudah pernah dilakukan sebelumnya, yaitu ekstrak air daun kelor dosis $300 \mathrm{mg} / \mathrm{KgBB}$ dapat menurunkan kadar glukosa darah pada tikus diabetes sebesar $44,06 \%$ (Edoga, 2013).

Berdasarkan uraian di atas, maka perlu dilakukan penelitian lebih lanjut terhadap ekstrak etanol $70 \%$ daun kelor yang diduga mempunyai potensi dalam menurunkan kadar trigliserida dan glukosa darah pada tikus putih jantan galur SD yang diinduksi dengan aloksan serta penambahan pakan tinggi trigliserida yang ditujukan untuk pendekatan patologi diabetes mellitus tipe 2. Pengukuran kadar trigliserida menggunakan fotometer klinikal varta-506 dan glukosa darah menggunakan haemoglukometer (Accu Check Active).

\section{METODE PENELITIAN}

Rancangan penelitian menggunakan rancangan acak lengkap dengan lima kelompok perlakuan. Penelitian dilakukan pada tikus putih jantan (Rattus novergicus L.) galur Sprague dawley dengan bobot 200-300 g. Bahan yang digunakan adalah daun kelor (Moringa oleifera Lam.), obat pembanding Fenofibrat dan 
Glibenklamid, penginduksi pakan tinggi trigliserida (kuning telur ayam $30 \%$, lemak sapi $20 \%$ dan makanan standar sampai 100\%) serta aloksan tetrahidrat (Kurniawan, 2008; Widyaningsih, 2011), reagen kit trigliserida dan strip glukosa darah. Peralatan yang digunakan kandang tikus, timbangan hewan, vacum rotary evaporator, sonde oral, haemoglukometer dan fotometer klinikal varta-506.

Daun kelor tua segar sebanyak $1 \mathrm{~kg}$ ditimbang, dibersihkan, dicuci, dikeringkan kemudian dihaluskan dan diayak dengan mesh no. 20 sampai diperoleh serbuk kering. Sebanyak 4,54 kg serbuk simplisia dimaserasi dengan etanol $70 \%$ selama 3 hari, kemudian disaring. Ampas dimaserasi kembali dengan larutan etanol 70\%, maserasi dilakukan sebanyak tiga kali. Maserat kemudian diuapkan dengan menggunakan vacum rotary evaporator hingga didapat ekstrak kental etanol 70\%. Ekstrak kental dikeringkan dengan oven pada suhu $50{ }^{\circ} \mathrm{C}$ sampai kering (Depkes RI 1986 ; Depkes RI, 2000a).
Penapisan fitokimia terhadap ekstrak daun kelor meliputi pemeriksaan alkaloid menggunakan pereaksi Dragendorf dan Mayer, uji flavonoid dengan serbuk magnesium, $\mathrm{H}_{2} \mathrm{SO}_{4}$ pekat dan $\mathrm{FeCl}_{3}$. Uji saponin dengan pembentukan buih, dan uji tanin menggunakan pereaksi $\mathrm{FeCl}_{3} 1$ $\%$. Uji steroid dilakukan jika terjadi perubahan warna merah atau ungu menunjukkan adanya triterpenoid dan warna hijau menunjukkan adanya steroid (Arifin, 2006). Pemeriksaan mutu ekstrak daun kelor meliputi pemeriksaan susut pengeringan (Depkes RI, 2000b) dan perhitungan rendemen ekstrak dengan cara menghitung berat ekstrak kering yang diperoleh terhadap berat serbuk kering sebelum dilakukan ekstraksi.

Pada penelitian kali ini, dibuat tiga variasi dosis ekstrak daun kelor yang berbeda yaitu : $150 \mathrm{mg} / \mathrm{Kg} \mathrm{BB}$, $300 \mathrm{mg} / \mathrm{Kg}$ BB dan $600 \mathrm{mg} / \mathrm{Kg}$ BB tikus. Dosis fenofibrat untuk tikus 9 $\mathrm{mg} / \mathrm{hari} / \mathrm{KgBB}$ tikus. Dosis glibenklamid untuk tikus 0,9 $\mathrm{mg} / \mathrm{hari} / \mathrm{KgBB}$. Dosis aloksan yang diberikan sebagai penginduksi 
diabetes berdasarkan orientasi yakni $140 \mathrm{mg} / \mathrm{KgBB}$ tikus secara intraperitoneal.

Perlakuan terhadap hewan uji

Penelitian dimulai dengan induksi larutan aloksan pada hari ke 7 dan ke 11 dengan masing-masing dosis $140 \quad \mathrm{mg} / \mathrm{KgBB} \quad$ secara intraperitoneal serta pemberian pakan tinggi trigliserida pada hari ke-1 sampai hari ke-14 ke semua kelompok tikus. Hari ke 15 dilakukan pengambilan darah puasa untuk pengukuran kadar glukosa dan trigliserida darah awal. Darah tikus diambil melalui ekor kira-kira $1 \mathrm{ml}$ kemudian disentrifugasi pada putaran $4000 \mathrm{rpm}$ selama 15 menit agar diperoleh serum darah. Pengukuran kadar trigliserida serum darah dengan cara mencampurkan serum sebanyak $10 \mu \mathrm{l}$ dengan $1,0 \mathrm{ml}$ reagen kit trigliserida. Campuran tersebut dihomogenkan dengan vorteks lalu diinkubasi selama 5 menit pada suhu $37^{\circ} \mathrm{C}$. Pengukuran Kadar trigliserida darah menggunakan fotometer klinikal (Kurniawan, 2008). Pengukuran kadar glukosa darah dengan cara darah diteteskan pada glukometer strip sampai kadar glukosa darah terukur.

$$
\text { Adapun perlakuan yang }
$$
diberikan yaitu semua tikus dibagi menjadi 6 kelompok masing-masing 5 ekor, dengan pembagian kelompok sebagai berikut :

Kelompok I : Diberi injeksi aloksan + pakan tinggi trigliserida + suspensi Na.CMC (kontrol negatif)

Kelompok II : Diberi injeksi aloksan + pakan tinggi trigliserida + pembanding Fenofibrat 9 $\mathrm{mg} / \mathrm{hari} / \mathrm{KgBB}$ tikus (kontrol positif) Kelompok III : Diberi injeksi aloksan + pakan tinggi trigliserida + pembanding Glibenklamid 0,9 $\mathrm{mg} / \mathrm{hari} / \mathrm{KgBB}$ tikus (kontrol positif) Kelompok IV : Diberi injeksi aloksan + pakan tinggi trigliserida + sediaan uji ekstrak daun kelor dosis $150 \mathrm{mg} / \mathrm{hari} / \mathrm{KgBB}$ tikus (dosis uji 1) Kelompok V : Diberi injeksi aloksan + pakan tinggi trigliserida + sediaan uji ekstrak daun kelor dosis $300 \mathrm{mg} / \mathrm{hari} / \mathrm{KgBB}$ tikus (dosis uji 2) Kelompok VI : Diberi injeksi aloksan + pakan tinggi trigliserida + 
sediaan uji ekstrak daun kelor dosis $600 \mathrm{mg} / \mathrm{hari} / \mathrm{KgBB}$ tikus (dosis uji 3) Pemberian sediaan pembanding, sediaan uji ekstrak dan CMC Na. diberikan selama 21 hari secara oral menggunakan sonde. Darah diambil pada hari ke 15 dan 36 setelah pemberian sediaan.

\section{HASIL DAN PEMBAHASAN}

Determinasi merupakan langkah awal dalam penelitian untuk mendapatkan identitas yang benar dari tanaman yang akan diteliti, sehingga dapat memberikan kepastian tentang kebenaran tanaman tersebut. Berdasarkan hasil determinasi, simplisia yang digunakan adalah benar daun Kelor (Moringa oleifera Lam.) dengan suku Moringaceae.

Daun kelor segar sebanyak 14 $\mathrm{kg}$ dicuci bersih lalu ditiriskan. Kemudian daun kelor dikeringkan. Pengeringan dilakukan untuk mencegah timbulnya bakteri dan jamur yang dapat menurunkan kualitas simplisia. Daun kelor kering diserbukkan dengan mesin penggiling sehingga didapat serbuk sebanyak 4,54 kg. Penyerbukan dilakukan untuk memperbesar luas permukaan simplisia menyebabkan pelarut yang digunakan mudah menyerap ke dalam simplisia sehingga senyawa aktif yang tertarik lebih maksimal (Depkes RI, 1986) .

Ekstraksi daun kelor dilakukan dengan cara maserasi. Maserasi merupakan cara penyarian yang mudah dan sederhana serta untuk bahan yang tidak tahan pemanasan atau zat aktif tersebut belum diketahui tahan panas atau tidak. Cairan penyari yang digunakan adalah etanol karena etanol merupakan salah satu cairan penyari yang umum digunakan untuk menarik zat aktif tanaman, etanol dapat digunakan sebagai bahan pengawet untuk mencegah pertumbuhan jamur, bakteri, kapang, dan lain-lain selain itu etanol juga dapat melarutkan alkaloid basa, flavonoid, steroid, damar, dan glikosida (Depkes RI, 1986). Pengujian susut pengeringan dimaksudkan untuk mengetahui berapa besar senyawa yang hilang ketika dikeringkan. Perolehan nilai 
susut pengeringan simplisia saponin, tanin dan steroid. Hasil

memenuhi persyaratan yaitu lebih penapisan fitokimia dapat dilihat kecil dari $10 \%$ (Depkes RI, 2000b). pada tabel III.

Hasil ekstraksi daun kelor dan uji Pengujian dilakukan dengan karakteristik mutu esktrak dapat menggunakan hewan uji tikus putih dilihat pada Tabel I dan II. jantan galur SD. Alasan

Hasil uji penapisan fitokimia menggunakan hewan uji tikus karena terhadap ekstrak daun kelor kelengkapan organnya dan susunan menunjukkan bahwa ekstrak daun darahnya mendekati manusia,

kelor mengandung senyawa alkaloid,

Tabel I. Hasil Ekstraksi Daun Kelor (Moringa oleifera Lam.)

\begin{tabular}{lc}
\hline \multicolumn{1}{c}{ Jenis } & Hasil (kg) \\
\hline Daun kelor segar & 14 \\
Serbuk daun kelor & 4,54 \\
Ekstrak etanol kering & 0,726 \\
\hline
\end{tabular}

Tabel II. Hasil uji karakteristik mutu ekstrak daun kelor

\begin{tabular}{lc}
\hline \multicolumn{1}{c}{ Jenis } & Hasil (\%) \\
\hline Rendemen ekstrak kering & 15,9767 \\
Susut pengeringan & 6,6614 \\
\hline
\end{tabular}

Tabel III. Hasil uji penapisan fitokimia ekstrak daun kelor

\begin{tabular}{lc}
\hline \multicolumn{1}{c}{ Uji Penapisan } & Hasil \\
\hline Alkaloid & + \\
Flavonoid & - \\
Saponin & + \\
Tanin & + \\
Triterpenoid & - \\
Steroid & + \\
\hline
\end{tabular}

Keterangan :

$+=$ ada $\quad-=$ tidak ada 
relatif resisten terhadap infeksi, bersifat tenang dan mudah ditangani, ekonomis, mudah didapat, mudah diperoleh dalam jumlah banyak. Tikus yang digunakan adalah tikus sehat dengan tanda-tanda mata jernih, bulu yang bersih, tingkah laku normal dan aktif.

Untuk meningkatkan kadar trigliserida digunakan makanan tinggi lemak berupa kuning telur, lemak sapi dan dicampur dengan pakan standar. Penelitian menggunakan enam kelompok yaitu tiga kelompok kontrol dan tiga kelompok perlakuan dengan bahan uji. Tiga kelompok kontrol yaitu 2 kelompok kontrol positif dan 1 kelompok kontrol negatif. Kontrol positif dibuat diabetes dengan larutan Aloksan tetrahidrat dosis 140 $\mathrm{mg} / \mathrm{KgBB}$ dan diberikan pakan tinggi trigliserida, kemudian dilanjutkan pemberian suspensi Fenofibrat 9 $\mathrm{mg} / \mathrm{KgBB}$ dan suspensi Glibenklamid $\quad 0,9 \mathrm{mg} / \mathrm{hari} / \mathrm{KgBB}$ tikus dengan Na-CMC 0,5\% sebagai zat pensuspensi selama 3 minggu. Sediaan uji ekstrak etanol $70 \%$ daun Kelor, pembanding Fenofibrat dan
Glibenklamid dibuat dengan menggunakan Na.CMC $0,5 \%$ sebagai pensuspensi (Anonim, 2003). Bahan pembanding yang digunakan pada penelitian ini adalah Fenofibrat dan Glibenklamid. Fenofibrat merupakan kongener asam fibrat (fibric acid) generasi pertama turunan clofibrat. Fenofibrat tersedia sebagai suatu ester metiletil yang dihidrolisis dengan sempurna di dalam usus. Diduga fenofibrat berfungsi sebagai ligan untuk PPAR$\alpha$. Obat tersebut bermanfaat pada hipertrigliseridamia yang didominasi VLDL dan untuk disbetalipoproteinemia.

Glibenklamid merupakan obat yang termasuk dalam golongan sulfonilurea. Mekanisme kerja obat ini adalah merangsang sekresi insulin di pankreas sehingga cocok untuk diabetes Mellitus tipe 2 karena pankreas masih dapat memproduksi insulin (Katzung, 2009). Dosis oral glibenklamid yang dipakai untuk manusia adalah $5 \mathrm{mg}-15 \mathrm{mg}$ sehari (Martindale, 2009).

Kontrol negatif, dibuat diabetes dengan larutan aloksan tetrahidrat 
dosis $140 \mathrm{mg} / \mathrm{KgBB}$ tikus dan gBB. Pada penelitian ini digunakan

diberikan pakan tinggi trigliserida, aloksan tetrahidrat sebagai serta larutan Na-CMC 0,5\% $1 \mathrm{ml} / 200$ penginduksi hiperglikemia sehingga

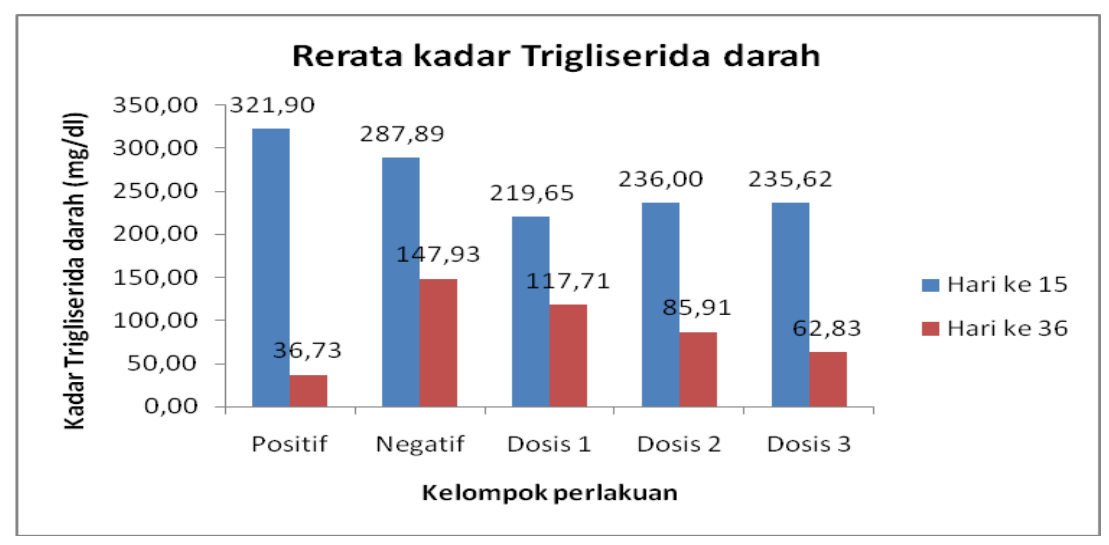

Gambar 1. Rerata kadar Trigliserida pada pemberian ekstrak daun kelor

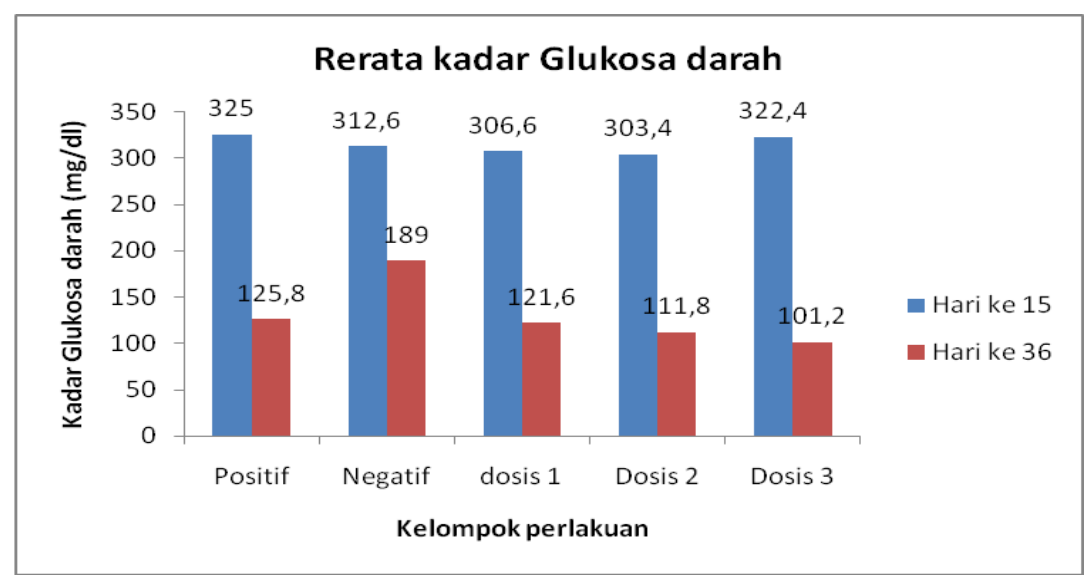

Gambar 2. Rerata kadar Glukosa pada pemberian ekstrak daun kelor 


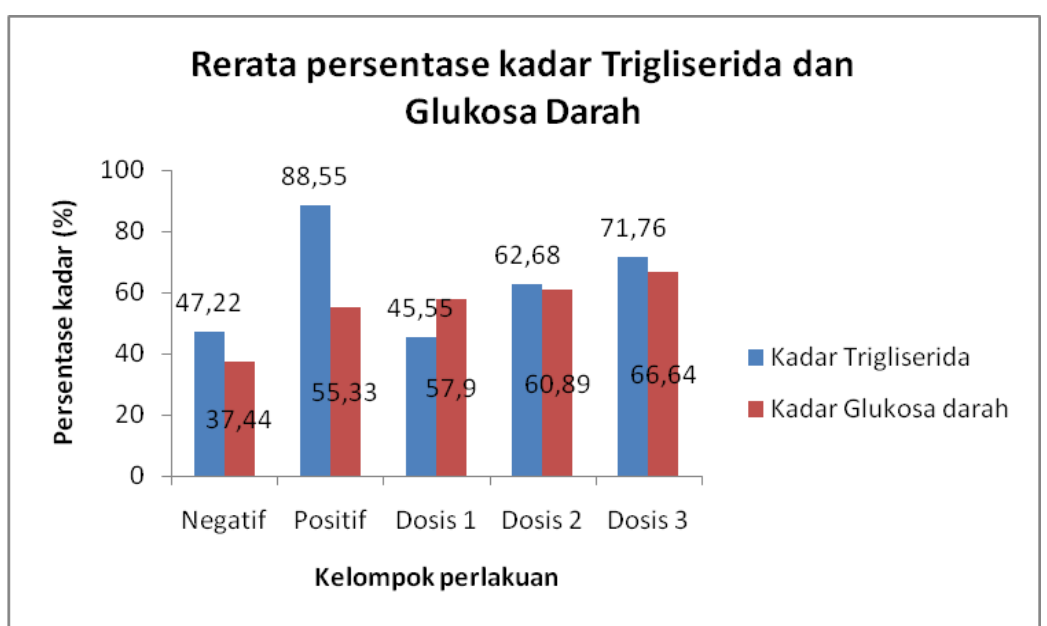

Gambar 3. Rerata persentase penurunan kadar trigliserida dan glukosa darah pada pemberian ekstrak daun kelor

kadar glukosa darah tikus menjadi tinggi. Zat tersebut mampu merusak pankreas. Prinsip kerja aloksan langsung pada sel $\beta$ pankreas membentuk khelat dengan zinc sehingga merangsang terbentuknya $\mathrm{H}_{2} \mathrm{O}_{2}$ dan merusak lisosom sel dan menyebabkan degenerasi dan reabsorpsi sel pankreas sehingga terjadi defisiensi insulin (Szukudelski, 2001).

Pengambilan dan pemeriksaan darah tikus dilakukan sebanyak dua kali yaitu pada hari ke 15 dan 36 . Rata-rata kadar trigliserida dan glukosa darah dapat dilihat pada gambar 1 dan 2. Persentase penurunan kadar trigliserida dan glukosa darah dapat dilihat pada gambar 3 .

Pada penelitian sebelumnya ekstrak air daun kelor dosis 300 mg/ KgBB mampu menurunkan kadar glukosa darah $44,06 \%$ pada tikus diabetes jika dibandingkan dengan ekstrak etanol $70 \%$ daun kelor dosis $150 \mathrm{mg} / \mathrm{KgBB}$ mampu menurunkan kadar glukosa $57,9 \%$ pada tikus diabetes, dosis $300 \mathrm{mg} / \mathrm{KgBB}$ mampu menurunkan kadar glukosa $60,89 \%$ pada tikus diabetes, dosis $600 \mathrm{mg} / \mathrm{KgBB}$ mampu menurunkan kadar glukosa $66,64 \%$ pada tikus diabetes. Berdasarkan hasil tersebut menunjukkan bahwa ekstrak etanol $70 \%$ daun kelor lebih mampu menurunkan kadar glukosa darah 
pada tikus diabetes. Hal ini dapat disebabkan karena penyarian yang dilakukan dengan pelarut etanol lebih maksimal menarik zat-zat aktif yang terkandung di dalam daun kelor dibandingkan penyarian yang dilakukan dengan pelarut air.

Pada kelompok negatif terjadi penurunan kadar glukosa darah sebesar 37,44 \%. Penyebabnya mungkin karena sifat aloksan monohidrat yang reversible dalam hal merusak sel beta pankreas. Sedangkan pada kelompok negatif terjadi penurunan kadar trigliserida sebesar 47,22\%. Hal ini dapat disebabkan karena kondisi lingkungan hewan uji yang membuat hewan uji menjadi stress dan pemberian makanan yang tidak merata pada tiap kelompok hewan uji sebagai akibat ada hewan uji yang sering makan tetapi ada juga yang sebaliknya hewan uji tidak sering makan.

Hasil Validasi Glukometer Accu-Check Active (Roche) dilakukan dengan cara membandingkan pengukuran AccuCheck Active (Roche) dengan
Spektrofotometer Cobas Mira Plus (Roche). Hasil akurasi yang didapatkan sebesar $-1,15 \%$ dan presisi sebesar 2,11\%. Hal ini menunjukan bahwa alat glukometer yang digunakan pada penelitian ini dalam kondisi baik karena berdasarkan Spesifikasi Alat Glukometer Accu-Check Active (Roche) hasil akurasi dan presisi tidak kurang dari $5 \%$.

Berdasarkan hasil analisa ANOVA $\quad(\alpha<0,05) \quad$ menunjukkan bahwa pemberian ekstrak daun kelor mempunyai pengaruh perlakuan terhadap penurunan kadar trigliserida dan glukosa darah tikus. Data kemudian dilanjutkan dengan uji Tukey untuk mengetahui perbedaan tiap kelompok perlakuan. Hasil uji tukey pada pengukuran kadar trigliserida darah terdapat perbedaan bermakna $(<0,05)$ antara kelompok kontrol negatif dengan kelompok positif, dosis II dan dosis III. Namun tidak ada perbedaan bermakna $(>0,05)$ antara kelompok kontrol negatif dengan kelompok dosis I serta antara kelompok dosis II dengan kelompok dosis III. Jadi 
dalam hal ini kelompok dosis II dan

III mempunyai efektivitas yang sama

dalam menurunkan kadar trigliserida darah akan tetapi tidak lebih baik dibandingkan dengan kelompok kontrol positif Fenofibrat.

Berdasarkan hasil uji tukey pengukuran kadar glukosa darah, data menunjukkan bahwa tiap dosis memperlihatkan efektifitasnya dalam menurunkan kadar glukosa darah. Data menunjukkan adanya perbedaan bermakna $(\mathrm{p}<0,05)$ antara kelompok kontrol negatif dengan kelompok yang diberi sediaan uji ekstrak daun kelor dan kontrol positif Glibenklamid. Hal ini menunjukkan bahwa kelompok kontrol positif dan kelompok yang diberi sediaan uji dapat menurunkan kadar glukosa darah secara bermakna dibanding kontrol negatif. Sedangkan antara kontrol positif dengan kelompok yang diberi sediaan uji tidak ada perbedaan bermakna. Dengan demikian data ini menunjukkan bahwa kelompok yang diberi sediaan uji mampu menurunkan kadar glukosa darah pada tikus yang diinduksi aloksan dan pakan tinggi trigliserida yang sebanding dengan kontrol positif Glibenklamid.

Pada penderita diabetes melitus akan terjadi kelainan metabolisme tubuh, dan salah satunya adalah lipid, yaitu peningkatan katabolisme lipid dengan peningkatan pembentukan benda-benda keton dan juga menurunnya sintesis asam lemak dan trigliserida. Dengan kelainan metabolisme lipid yang besar inilah, maka diabetes melitus sering disebut sebagai suatu penyakit metabolisme lemak. Lima puluh persen glukosa yang dimakan dibakar menjadi $\mathrm{CO}_{2}$ dan $\mathrm{H}_{2} \mathrm{O}$, lima persen diubah menjadi glikogen, dan sekitar 30-40\% diubah menjadi lemak dalam depot lemak. Bagi penderita diabetes melitus terjadi penurunan pengubahan glukosa menjadi asam lemak dalam depot karena defisiensi glukosa intrasel. Insulin menghambat lipase sensitive hormone dalam jaringan adiposa, dan tanpa enzim ini kadar asam lemak bebas plasma lebih dari dua kali. Peningkatan glukagon juga meningkatkan mobilisasi asam lemak. Jadi, pada penderita diabetes melitus kadar lemak bebas paralel 
dengan kadar glukosa darah merupakan indikator baik mengenai beratnya diabetes melitus (Sibernagi, 2007).

\section{KESIMPULAN}

Ekstrak etanol $70 \%$ daun
kelor (Moringa oleifera Lam.)
dengan dosis 300 dan 600
mg/KgBB mempunyai aktivitas yang
sama dalam menurunkan kadar
trigliserida darah tikus yang
diinduksi aloksan dan pakan tinggi
trigliserida dibandingkan dengan
kontrol positif Fenofibrat dosis 9
mg/KgBB. Semua dosis ekstrak
etanol $70 \%$ daun kelor mempunyai
kemampuan menurunkan kadar
glukosa darah tikus yang diinduksi
aloksan dan pakan tinggi trigliserida
sebanding dengan Glibenklamid
dosis 0,9 mg/Kgbb.

\section{DAFTAR PUSTAKA}

Anonim., 2003, Handbook of Pharmaceutical Exipient. $4^{\text {th }}$ edition. Editor : Raymond C. Rowe, Paul J Sheskey dan Marian E. Quinn. Hlm. 97.

Arifin H, Nelvi A., 2006, Standarisasi Ekstrak Etanol
Daun Eugenia cumini Merr, Jurnal Sain dan Teknologi Farmasi, vol 11 no. 2. Padang.

Corwin J E., 2009, Buku Saku Patofisiologi, Terjemahan : Nike Budhi Subekti. EGC, Jakarta. Hlm. 625.

Departemen Kesehatan RI., 1986, Sediaan Galenika, Ditjen Pengawasan Obat dan Makanan. Departemen Kesehatan Republik Indonesia, Jakarta. Hlm. 3-16.

Departemen Kesehatan RI., 2000a, Buku Panduan Teknologi Ekstrak, Direktorat Jendral Pengawasan Obat dan Makanan. Departemen Kesehatan Republik Indonesia, Jakarta. Hlm. 3,6,11-15,17,39.

Departemen Kesehatan RI., 2000b, Parameter Standar Umum Ekstrak Tumbuhan Obat. Departemen Kesehatan RI,. Jakarta. Hal 13-17.

Departemen Kesehatan RI., 2005, Pharmaceutical Care Untuk Penyakit Diabetes Mellitus. Departemen Kesehatan RI, Jakarta. Hlm. 7.

Departemen Kesehatan RI., 2012, Tahun $2030 \quad$ Prevalensi Diabetes Melitus Di Indonesia Mencapai 21,3 Juta Orang. http: // www. depkes. go. $\mathrm{id} /$ index.php/berita/pressrelease/414-tahun-2030prevalensi-diabetes-melitus-diindonesia mencapai-213-jutaorang.html. Diakses 27 Oktober 2012.

Edoga CO., 2013, Blood Sugar Lowering Effect of Moringa Oleifera Lam in Albino Rats. International Journal of 
Science and Technology. University of Nigeria, Nsukka, Enugu State, Nigeria. Hlm.8890.

Josten S., 2006, Profil Lipid Penderita Diabetes Mellitus Tipe 2., Indonesian Journal of Clinical Pathology and Medical Laboratory, Vol 13. HIm. 20.

Kasolo, J. N., Bimenya, G. S., Ojok, L., Ochieng, J., and Ogwalokeng, J. W., 2010, Phytochemicals and uses of Moringa oleifera leaves in Ugandan rural communities, Journal of Medicinal Plants Research, 4(9): 753-757.

Katzung., 2009, Pancreatic Hormone and Antidiabetic Drugs, Basic \& Clinical Pharmacology $10^{\text {th }}$ ed. Mc Graw Hill Companies.

Kurniawan DT., 2008, Uji Aktivitas Fraksi n-Heksana Akar Seledri (Apium graveolens L.) Terhadap Penurunan Kadar LDL Kolesterol Darah Tikus Putih Jantan yang Diinduksi Makanan Tinggi Kolesterol dan Indentifikasi Senyawa
Aktifnya dengan GCMS, Skripsi, Jakarta. Hlm. 38.

Martindale., 2009, The Complete Drug Reference, thirty sixth edition. Pharmaceutical Press.

Sibernagi S, Lang F, . 2007, Teks dan Atlas Patofisiologi: Penyakit Jantung Koroner. Jakarta. EGC.

Szkudelski T., 2001,. The mechanism of alloxan and streptozotocin action in $b$ cells of the rat pancrea. Hal.537-46.

Widyaningsih W., 2011, Efek Ekstrak Etanol Rimpang Temugiring (Curcuma heyneana val) Terhadap Kadar Trigliserida, Jurnal Ilmiah Kefarmasian, Vol. 1. Hlm. 60. 